Палагусинець Ростислав Васильович кандидат економічних наук, заступник керівника відділу Управління забезпечення міжпарламентських зв'язків Апарату Верховної ради України, вул. Грушевського, 5, м.Київ, 01008, тел.: (044) 255-30-83, e-mail: palarost@ gmail.com, https://orcid.org/0000-0003-1399-7164

\title{
ДЕРЖАВНЕ УПРАВЛІННЯ В СИСТЕМІ ДИПЛОМАТИЧНИХ СЛУЖБ: КАДРОВА ПОЛІТИКА
}

Анотація. У статті досліджується державне управління як один із важливих структурних елементів в системі органів дипломатичних служб України у сучасних міжнародних відносинах. Проаналізовано трактування сутності категорії «дипломатична служба» та «методу управління кадрового процесу». Досліджено основні заходи та методи задля імплементації кадрової політики, які визначають основні кадрові процеси. Визначено основні проблеми кадрового забезпечення дипломатичної служби України, та описано поточний процес відбору претендентів на зайняття вакантних посад у дипломатичних установах України і сформовано деякі шляхи удосконалення механізмів підбору дипломатичних кадрів України. Вивчено деякі аспекти державного управління в системі дипломатичної служби, які регулюються Конституцією України та Законами "Про дипломатичну службу України", "Про державну службу", Трудовим кодексом України, Консульським статутом України, а також іншими нормативними актами та існуючі міжнародні договори. Досліджено основні елементи діяльності дипломатичних представництв, де основні аспекти роботи базуються на захисті інтересів та законних прав та свобод громадян країни за кордоном та реалізації безпеки суспільства та держави. У дослідженні наведені достовірні службові дані фактичних показників кадрового складу дипломатичної служби України за період з 2017-2020 pp. Проаналізовано кількісні показники щодо мовної підготовки та професійного навчання штатних працівників дипломатичної служби. Оцінено результативні показники діяльності працівників закордонних дипломатичних установ за 2017-2020 pp. та рівень вчасно виконаних доручень та частки прийнятих нормативно-правових актів у загальній кількості розроблених. Описано розроблені відповідні пропозиції, в тому числі проєктів законодавчих актів, щодо посилення інституційної спроможності органів дипломатичної служби України, задля реалізації ефективної кадрової політики, яка має імплементуватися протягом 2020 року.

Ключові слова: дипломатична служба, державна служба, кадровий процес, кадрова політика, кадровий склад, закордонні дипломатичні установи.

Palagusynets Rostyslav Vasyliovych Ph.D. in Economics, Deputy Head of the Department of Interparliamentary Relations of the Office of the Verkhovna Rada of Ukraine, Grushevsky str., 5, Kyiv, 01008, tel.: (044) 255-30-83, e-mail: palarost@gmail.com, https://orcid.org/0000-0003-1399-7164 


\title{
PUBLIC ADMINISTRATION IN THE SYSTEM OF DIPLOMATIC SERVICES: PERSONNEL POLICY
}

\begin{abstract}
The article examines public administration as one of the important structural elements in the system of bodies of the diplomatic services of Ukraine in modern international relations. The interpretation of the essence of the category "diplomatic service" and "method of managing the personnel process" is analyzed. Main activities and methods for the implementation of personnel policy, which determine the main personnel processes, have been investigated. The main problems of staffing the diplomatic service of Ukraine are identified, and the current process of selection of applicants for vacant positions in diplomatic institutions of Ukraine is described, and some ways are formed to improve the mechanisms for the selection of diplomatic personnel in Ukraine. Some aspects of public administration in the system of the diplomatic service are studied, they are regulated by the Constitution of Ukraine and the laws "On the diplomatic service of Ukraine", "On public service", the Labor Code of Ukraine, the Consular Charter of Ukraine, as well as other regulations and existing international treaties. The main elements of the activities of diplomatic missions, where the main aspects of work are based on the protection of the interests and legal rights and freedoms of citizens of the country abroad and the implementation of the security of society and the state, have been studied The study provides reliable service data of the actual indicators of the personnel of the diplomatic service of Ukraine for the period from 2017-2020. The quantitative indicators of language training and professional training of staff members of the diplomatic service are analyzed. The performance indicators of employees of foreign diplomatic institutions for 2017-2020 were evaluated. And level of orders completed on time and the share of the adopted regulatory legal acts in the total number of developed ones. Relevant proposals, including draft legislative acts, to strengthen the institutional capacity of the bodies of the diplomatic service of Ukraine, to implement an effective personnel policy, which should be implemented during 2020, are described.
\end{abstract}

Keywords: diplomatic service, civil service, personnel process, personnel policy, personnel, foreign diplomatic institutions.

Постановка проблеми. Оскільки дипломатична служба являється невідокремленим структурним елементом державної служби України, яка формує та реалізує зовнішню політику України на міжнародній арені та відстоює інтереси держави і громадян керуючись нормативно-правовими нормами міжнародного та національного законодавства. У дослідженні поставлено завдання визначити роль кадрової політики у системі дипломатичної служби задля формування ефективного державного управління зовнішньої політики держави.

Оскільки кадрова політика визначає посилення ролі потенційного працівника дипломатичної служби таким, від якого залежить ефективність реалізації поставлених завдань, тому що відбуваються значні структурні перетворення на міжнародній арені та в сучасних міжнародних відносинах. У зв'язку із науковотехнічним прогресом та розвитком новітніх інформаційних технологій, 
відбувається поглиблення протиріч сучасної світової економіки та загострення глобальної конкуренції, з однієї сторони, та зростання взаємозалежності держав, 3 іншої сторони, спричиняє більш високі вимоги до якості дипломатичного персоналу, яка базується на основі знань, навичок, , здатності до самовдосконалення, розвитку та прийняття рішучих свідомих дій.

Тому вимоги до професійного дипломату, окрім володіння спеціальними знаннями, зобов'язують розуміння складних процесів міжнародних відносин як єдиної системи, де необхідно імплементувати правильні самостійні рішення та висновки та вибирати прийнятні варіанти для реалізації поставлених державою завдань. Сучасна міжнародна діяльність країни на світовій арені вимагає високопрофесійних спеціалістів, де за даних вимог, механізми кадрового забезпечення дипломатичної служби повинні бути якомога досконалішими.

Аналіз останніх досліджень і публікацій. Тематику державного управління, дипломатичної служби та iї кадрової політики досліджує значна кількість науковців. Зокрема, наукові праці А. О. Гончарова, Б. I. Гуменюк, В. С. Загорський, М. І. Карпа, Н. І. Пахомова, О. В. Щерба, О. С. Чмельова, С. О. Телешун, Ю. В. Ковбасюк, Ю. В. Чуйко присвячені аналізу деяких аспектів становлення кадрової політики сучасної дипломатичної служби України в рамках глобалізаційних процесів, які вплинули на розвиток та становлення державної служби та їі зовнішньополітичну діяльність. Значну роботу з аналітичної оцінки дипломатичної служби здійснюють експерти Міністерства закордонних справ України.

Метою роботи $є$ дослідження ролі державного управління в системі дипломатичної служби задля формування результативної кадрової політики. Для досягнення мети визначено наступні завдання:

1. визначити основні заходи i методи для імплементації кадрової політики в системі дипломатичної служби;

2. описати поточний процес відбору претендентів на зайняття вакантних посад у дипломатичних установах України;

3. проаналізувати кадровий склад дипломатичної служби України.

При проведенні дослідження були використані загальнонаукові й спеціальні методи дослідження, зокрема аналіз і синтез, порівняння, узагальнення, системноструктурний аналіз, статистичний аналіз, графічний, політологічний та геополітичний методи.

Виклад основного матеріалу. Оцінюючи кадрові питання та стратегічну політику у контексті становлення державного управління в системі дипломатичної служби в Україні вимагає детального дослідження, адже кадрова політика державної служби постійно видозмінюється та модернізується застосовуючи при цьому різноманітні методологічні підходи, інноваційні наукові доробки, світовий досвід теорії та практики функціонування кадрових процесів. Визначені відповідно до кадрової політики органів публічної влади основні напрями формування та розвитку кадрових процесів потребують теоретичного обгрунтування, детального вивчення та практичного використання теоретичних напрацювань.

Прикладами деяких кадрових процесів на практиці у межах національного рівня можна вважати розробку концепції державної кадрової політики, 
формування шляхів і механізмів кадрового забезпечення, створення цільових кадрових програм, виконання планів роботи з кадрами і кадрових програм тощо. Тому вивчення методів управління даними та іншими кадровими процесами $\epsilon$ необхідним та актуальним.

Зокрема, невирішеною частиною залишається формування єдиного теоретикометодологічного базису для забезпечення таких процесів, розробка категорійного апарату з позиції системного підходу для формування концептуальних підходів до державної служби. На сьогодні існує безліч методів державного управління, а також розробляється методологія державного сучасного управління та інших галузей знань, застосовуючи при цьому методологію окремих галузей господарства задля поточних потреб формування методології державного управління, задля становлення ефективного управління в системі дипломатичної служби. Тому найбільш широко використовуваним способом пізнання є системна методологія, а результатом застосування якої є синтезування практики, пізнання, норм, та пошуку необхідних методів [1, с. 354-355].

На загальнодержавному рівні кадровий процес в системі дипломатичної служби включає: розробку стратегічної концепції державної кадрової політики, формування поточних шляхів і механімів кадрового забезпечення, створення цільових кадрових програм, виконання встановлених планів роботи 3 кадрами i кадрових програм, та імплементація основних кадрових програм [2, с. 189]. Тому сучасні наукові доробки та практичні напрацювання в основному скеровані на кадрові процеси на рівні діяльності окремих органів державного управління в системі дипломатичної служби які безумовно у більшості випадків похідні від загальнодержавних. У кожному із зазначених напрямів для імплементації кадрової політики проводять наступні заходи, які визначають головні кадрові процеси:

— відповідну розробку стратегічної концепції державної кадрової політики;

- формування необхідних механізмів задля кадрового забезпечення;

- створення та імплементація цільових кадрових програм;

— виконання визначених планів роботи з кадрами та кадрових програм;

- втілення основних кадрових програм;

— формування відповідної стратегії підбору кадрів задля заміщення вакантних посад;

— визначення поточних процесів розстановки кадрів;

— формування поточної процедури прийому та звільнення персоналу;

- проведення підготовки, перепідготовки та можливість підвищення кваліфікації та компетентності персоналу;

- створення та реалізація відповідних стандартів кваліфікації працівників;

- проведення ідентифікації кадрового складу за якісними та особистими показниками;

— проведення контролю результатів праці дипломатичного працівника;

- формування мотивуючих та стимулюючих засобів, задля ефективної діяльності працівника;

— розробка підходів управління 3 врахуванням індивідуальних якостей працівників; 
- комплектування та ефективне застосування кадрового резерву;

— проведення заходів задля підвищення престижності роботи в дипломатичних органах;

— формування чіткого розподіл функцій, завдань та відповідальності за їх здійсненням;

- проведення заходів задля запобігання корупційних дій.

Зазначені кадрові процеси є основними об'єктами управління та вимагають необхідного інструментарію задля прийняття відповідних кадрових рішень, та застосування спеціальних методів для здійснення кадрової політики. Трактування поняття «методу управління кадровими процесами» визначається як систематизований спосіб владного впливу на процес розвитку кадрових процесів, функціонування кадрових служб, конкретних посадових осіб, діяльність яких призводить до вирішення поставлених кадрових питань, ефективного використання кадрового потенціалу, підвищення ефективності кадрового забезпечення дипломатичної служби.

Методи кадрових процесів націлені на практичну імплементацію кадрових рішень, які провадять управлінський вплив на об'єкти управління відповідно до цілей та завдань кадрової політики державної служби та політики органів дипломатичної служби. Даний вплив може здійснюватися як безпосередньо на кадрові процеси, так і опосередковано, мати короткострокову чи довгострокову дію. Основними методами управління кадровими процесами в органах дипломатичної служби вирізняються наступними основними функціями: стимулювання; контролю; активізації; стабілізації; регламентування; посилення мотивації персоналу; нормування; коректування кадрової політики; прогнозування кадрових процесів; проектування; кадрове моделювання тощо [1, с. 356-357].

На сьогоднішньому етапі основним принципом кадрової роботи виступає індивідуальний підхід до кандидатів у співробітники та поточних співробітників, при цьому використання їх особисті якості задля досягнення та гармонізації власних, колективних та державних інтересів, що надасть можливість якнайкраще реалізувати та імплементувати поточні поставлені завдання. Спеціальну увагу необхідно приділяти питанню поточним володінням майбутнім співробітником, як універсальними теоретичними знаннями, так і спеціальними, тобто знання специфіки функціонування дипломатичної служби, майбутньої конкретної роботи, особистих зв'язків, культури та моделі спілкування тощо.

Департамент персоналу Міністерства закордонних справ України здійснює діяльність зосереджену на підбір фахівців для забезпечення потреб як центрального апарату, так i закордонних дипломатичних установ. У даному процесі досить важливими $є$ наступні напрями його діяльності, а саме:

1) необхідність дотримуватись послідовної кадрової політики установи, де необхідно чітко визначити наступні вимоги: здійснення кадрового маркетингу, а саме аналіз ринку робочої сили, котра може бути залучена до дипломатичної служби, професійний підбір та розстановка кадрів, рекомендації щодо необхідності підвищення кваліфікації персоналу, робота по ротації кадрів, координація загальних завдань та планів кадрового забезпечення [3]; 
2) потрібно якісно реалізовувати та імплементувати наступні функції: встановлювати джерела комплектування кадрів, аналізувати поточний стан плинності кадрів та створювати пропозиції стосовно необхідності скорочення кадрів, реалізовувати оформлення прийняття, звільнення, переміщення співробітників всередині дипломатичної установи, формувати необхідні списки кадрового резерву, проводити поточний облік порушень трудової дисципліни та формувати рекомендації задля їх усунення [4, с. 66].

Згідно 3 правовою доктриною трактування поняття «дипломатичної служби» тлумачать як спеціальний вид професійної службової діяльності [5, с. 421]. У Законі України «Про дипломатичну службу» в статті 1 інтерпретується поняття «дипломатичної служби» яка визначається як професійна діяльність громадян України, яка скерована на практичну реалізацію зовнішньополітичної діяльності України, захист національних інтересів країни у сфері міжнародних відносин, а також прав та інтересів громадян та фізичних та юридичних осіб України за кордоном [6].

Згідно $з$ наданими повноваженнями спеціального органу державної влади, а саме Міністерства закордонних справ України, діяльність дипломатичного апарату України здійснюється виключно на державному рівні [7]. У зв'язку з проходженням дипломатичної служби формуються дипломатичні зносини, які регулюються Конституцією України, та наступними законами: «Про дипломатичну службу України» [6], «Про державну службу» [8], Кодексом законів про працю України, Консульським статутом України, а також іншими нормативно-правовими актами та чинними міжнародними договорами, де дозвіл на обов'язковість яких надана Верховною Радою України [5, с. 420].

Прийняття на дипломатичну службу визначається Законом України "Про дипломатичну службу" та довершується на конкурсній основі, за виключенням обставин, коли призначення осіб на дипломатичні посади втілює Президент України [6]. Поточний порядок проведення конкурсу відбувається на основі затвердженої постанови КМУ від 16.11.2001 року № 1754, а задля забезпечення проведення даного конкурсу відповідно до наказу Міністерства закордонних справ формується спеціальна конкурсна комісія. Конкурс проводиться у наступній черговості: спочатку публікується оголошення стосовно проведення відповідного конкурсу в засобах масової інформації, приймаються пакет документів від зацікавлених претендентів взяти участь у даному конкурсному відборі, де здійснюється попередній розгляд на відповідність кваліфікаційним вимогам, відтак проводиться іспит та селекція кандидатів [9].

Опубліковане оголошення стосовно відповідного конкурсу містить детальну інформацію стосовно назви вакантної посади, основні вимоги яким повинні відповідати кандидати згідно 3 типовими професійно-кваліфікаційними характеристиками посад державних службовців, поточний термін подання документів в загальному триває 30 календарних днів після подання публікації на розголошення з необхідною додатковою інформацією. Подані кандидатами пакет документів проходить процедуру розгляду на відповідність кваліфікаційним вимогам задля прийняття на дипломатичну службу. 
Кандидати документи яких не відповідають поточним вимогам до конкурсу не допускаються. Пакет документів, які були надіслані до Міністерства закордонних справ пізніше зазначеного терміну, не приймаються. Також до конкурсу не допускаються кандидати, котрі досягли, відповідно до законодавства, досягнення граничного віку перебування на державній службі, або визнані недієздатними, мають судимість, яка несумісна з посадою державного службовця, при прийнятті на дипломатичну службу будуть підпорядковуватись близьким родичам, або позбавлені права займати відповідні посади, у зв’язку із станом здоров'я не можуть направлятись у довготермінове закордонне відрядження, або не мають відповідної вищої освіти та у інших випадках визначених чинним законодавством.

Кандидати, котрі допущені до даного конкурсу після прийому та розгляду документів, здають кваліфікаційний іспит на знання законів України, володіння іноземними мовами та проходять співбесіди у відповідних підрозділах міністерства. Департамент персоналу Міністерства закордонних справ встановлює дату проведення кваліфікаційного іспиту та інформує кандидатів стосовно часу та місця проведення. Кваліфікаційний іспит сформований у вигляді екзаменаційних білетів, котрі проходять шляхом комп'ютерного тестування, виключно на державній мові. Кандидати на даному іспиті демонструють знання Конституції України, Законів України "Про державну службу", "Про дипломатичну службу", інших законів, міжнародних договорів тощо. Кандидати, котрі не склали кваліфікаційний іспит, вибувають з даного конкурсу.

Рівень володіння іноземними мовами оцінюється Вищими курсами іноземних мов Дипломатичної академії України при Міністерстві закордонних справ України за направленням Департаменту персоналу. Після розгляду поданого пакету документів, отримання результатів кваліфікаційного іспиту, відповідного контролю знання іноземних мов та проведеної співбесід, здійснюється поточний відбір претендентів задля аудієнції на дипломатичну службу, котру реалізує конкурсна комісія. Претенденти, котрі за результатами конкурсного відбору пройшли з позитивними результатами, проте не були вибрані для зарахування на дипломатичну службу, претенденти які погодилися, будуть зарахованими до кадрового резерву які рекомендуються конкурсною комісією. У випадках коли не відібрано жодного кандидата, повторно оголошується новий конкурс. Оцінюючи поточний процес добору кадрів для призначення на дипломатичну службу за конкурсною системою формує необхідні умови задля об'єктивного відбору кваліфікованих спеціалістів.

Основана частина дипломатичних працівників, які були прийняті на дипломатичну службу в останні роки, має відповідну освіту, вільно володіють двома іноземними мовами i демонструють здатність до набуття необхідних кваліфікаційних навичок. Проте дана конкурсна система підбору потенційних кадрів має низку прогалин та вимагає вдосконалення даної процедури відповідно до специфіки дипломатичної служби, яка спричинена надзвичайно високою складністю завдань у зовнішній сфері державної діяльності та зобов'язує від дипломатичного працівника ефективної діяльності як в середині країни, так і за їі межами. Також не є прийнятним довготривалий процес конкурсного відбору потенційних кадрів на дипломатичну службу, тому необхідно сформувати 
процедуру активного використання можливості прийняття на дипломатичну службу кандидатів з кадрового резерву. Дана процедура зобов’язує формування якісного кадрового резерву дипломатичної служби, що, в свою чергу, потребує підвищення ефективності функціонування Департаменту персоналу Міністерства закордонних справ України в даному напрямі.

Задля досягнення ефективного функціонування кадрового складу дипломатичної служби України необхідно удосконалювати поточні методи відбору кадрів та процес проходження дипломатичної служби даними кадрами таким способом, задля посилення врахування всіх психологічних якостей та здібностей, та готовності брати на себе відповідальність, тобто осіб, які приймаються на дипломатичну службу. При проведенні конкурсу на заміщення вакантних посад доцільно проводити співбесіду або відповідне тестування разом з психологом для визначення особистих якостей кандидатів. Оскільки в дипломатичній службі невід'ємною частиною робочого процесу являються довготермінові закордонні відрядження, тому дані співбесіди $є$ досить необхідними. Адже врахувавши психологічні якості дипломатичних працівників, дана процедура полегшить формування безконфліктних колективів закордонних дипломатичних установ, знизить рівень зародження конфліктів, дозволить уникнути інших непорозумінь та проблем, що в результаті буде сприяти підвищенню ефективності функціонуванню даних установ.

Загально відомим фактором щодо психологічного клімату закордонної дипломатичної установи являється вплив як мікро, так і макросередовища. Якщо на поточний клімат макросередовища, тобто того соціального простору, де знаходиться, живе та здійснює діяльність колектив закордонної дипломатичної установи, вплинути неможливо, то формування позитивного мікросередовища $\epsilon$ досить вагомим завданням кадрового менеджменту міністерства. Задля забезпечення даного середовища, необхідно досліджувати та ураховувати ознаки суспільно-економічного розвитку країни, де функціонує відповідний дипломатичний колектив.

Також, при формуванні закордонних дипломатичних установ важливим фактором психологічного клімату мікросередовища $є$ кількісний склад закордонної установи, оскільки обмежене спілкування теж формує додаткове психологічне навантаження на його членів, тому не кожна особистість зможе ефективно виконувати свої професійні обов'язки в даних умовах. 3 огляду на те надзвичайно важливо знати, ретельно аналізувати та враховувати психологічні якості потенційних співробітників при відборі та призначенні кадрів закордонних дипломатичних установ.

Однією з суттєвих особливостей дипломатичної служби, являється наступне, що працівники закордонних установ мають володіти як глибокими фаховими знаннями, так і особливими психологічними якостями, що дозволить якнайкраще виконувати поставлені обов'язки та завдання. Тому, з метою виявлення найбільш відповідних кандидатів на вакантні посади, можна застосовувати професіограми, які повинні бути розроблені за участі Департаменту персоналу Міністерства закордонних справ. 
Професіограма являється системним описом професійних та психологічних якостей, якими повинен володіти кандидат на відповідну посаду, де визначено коло його обов'язків та функцій. В загальному існує професіограма котра містить дві моделі:

1) модель необхідного співробітника, де зазначені професійні, ділові, особисті якості;

2) модель посади, де зазначені функції, обов'язки, завдання, відповідальність тощо.

Тому, застосовуючи професіограми та використовуючи відомості, стосовно конкретних ділових та психологічних якостей кандидатів надає можливість проведення якісного відбору та кореляційного залучення у подальшій роботі, оскільки даний механізм зводить до мінімуму суб'єктивний фактор та посилює об'єктивний при підборі та призначенні потенційних кадрів. Тому при відборі кадрів дипломатичної служби потрібно оцінювати особисті якості кандидатів, при цьому враховуючи наступні сфери: освіта, досвід, інтелект, вміння швидко осмислити суть проблеми, навички публічного виступу, здоров'я, психотип, комунікабельність, зовнішній вигляд, культура поведінки, власні інтереси та відповідні особисті обставини [4, с. 66-67].

Загалом штатний працівник дипломатичної служби являється не просто громадянином України, котрий свідомо приєднався до закордонних дипломатичних установ на державну службу, а також високопрофесійний фахівець, який сумлінно здійснює державні службові обов'язки у встановленому порядку до чинного державного законодавства за коштами державного бюджету. Адже працівник даної структури являється індивідом, що репрезентує та відстоює державні інтереси, виступаючи від імені та за дорученням держави у вирішенні нагальних міжнародних питань, які стосуються його компетенції. Сучасний дипломат повинен уособлювати наступні головні кваліфікаційні якості як сумлінність та професіоналізм на службі державі та українському суспільству.

Оскільки служба в дипломатичних установах являється досить специфічною сферою професійної діяльності, де основною своєрідністю даної роботи є:

1) націленість на захист інтересів, гарантування безпеки суспільства та держави на міжнародній арені;

2) не порушувати та захищати законні права та свободи громадян країни за кордоном;

3) убезпечення невимушеної участі громадян у державних справах;

4) стратегічний курс на імплементацію владних повноважень, а також політичних i соціальних державних завдань, a саме: інформаційноаналітичних, організаційно-управлінських, фінансово-господарських завдань;

5) імплементація управлінських функцій державно-політичного адміністрування;

6) формування відповідних засад для незагрозливого та достойного життя будьякої людини [5, с. 421].

Україна зосередженна на формування відповідної системи державної служби, яка тримає свій дипломатичний курс на приєднання, заохочення та утримання 
найкращих штатних працівників дипломатичного корпусу та санкціонує своєчасне позбавлення від професійно непридатних службовців. У прямо-пропорційній залежності знаходиться кар'єрний ріст дипломатичного службовця, а також його звання, класи та ранги від індивідуальних професійних досягнень, набутих професійно-ділових якостей та результативних показників роботи, які не залежать від статі, раси, національності, фінансового положення, релігійних і політичних орієнтації, місця проживання, походження. Головними професійними рисами дипломатичного службовця $є$ присутність особливих знань, умінь та навичок; професійна підготовленість до реалізації посадових обов'язків; відповідальне ставлення до дипломатичної справи та великий ступінь духовно-моральної культури, а також обов'язковою необхідністю для службовця є наявність широкого політичного кругозору, знання іноземних мов, спостережливість та вміння розпізнати істину [10, с. 67].

На новому етапі становлення зовнішньої політики та міжнародних відносин Україна інтегрується у європейське співтовариство та бере участь у міжнародних організаціях за наступними напрямами співробітництва з СС у галузях юстиції, свободи та безпеки, безвізового діалогу з СС, регіонального співробітництва з $\mathrm{CC}$, допомога у сфері інституційної розбудови зі сторони $\mathrm{CC}$, консультативна місія $\mathrm{CC}$ 3 реформування сектору цивільної безпеки України, співробітництва в енергетичній сфері та інвестиційного співробітництва, торговельного та економічного співробітництва, особливого партнерства 3 НАТО. Менеджмент сучасних відносин України з СС та 3 іншими державами та міжнародними організаціями забезпечує сучасна дипломатична служба України [11, с. 269].

В Україні станом на березень 2019 року було акредитовано одне Представництво Європейського Союзу, ГУАМ, яка являється однією міжнародною регіональною організацією, одна міжурядова організація, дві моніторингові місії та одна консультативна місія, а також 77 посольств іноземних держав та 18 представництв міжнародних організацій, де загальна кількість даних установ становить 101 штуку. Консульські установи іноземних держав станом на березень 2019 року представлені в Україні 21 генеральним консульством та 6 консульствами, і 103 почесними консульствами.

Станом на 1 січня 2020 р. згідно 3 бюджетною програмою за рахунок державних коштів було забезпечено функціонування 126 ЗДУ України. Середньорічна чисельність працівників ЗДУ склала 1261 особа, а загальна чисельність штатних працівників, які здійснюють консульські функції, склала 299 осіб. Враховуючи суттєве збільшення обсягів консульських дій у країнах Східної Свропи, було збільшено чисельність консульських працівників, за рахунок перерозподілу обов'язків серед працівників ЗДУ та забезпечено організацію виконання поставлених завдань на належному рівні (див. табл. 1) [12]. 
Таблиия 1

Кадровий склад закордонних дипломатичних установ за 2017-2020 pp.

\begin{tabular}{|c|c|c|c|c|c|c|c|c|}
\hline \multirow[t]{2}{*}{ Показники } & \multicolumn{4}{|c|}{$\begin{array}{c}\text { Затверджено у паспорті } \\
\text { бюджетної програми (ЗУПБП) }\end{array}$} & \multicolumn{4}{|c|}{$\begin{array}{c}\text { Фактичні результативні } \\
\text { показники (ФР3) }\end{array}$} \\
\hline & 2017 & 2018 & 2019 & 2020 & 2017 & 2018 & 2019 & 2020 \\
\hline $\begin{array}{l}\text { Кількість діючих закордонних } \\
\text { дипломатичних установ (ЗДУ) } \\
\text { України }\end{array}$ & $\begin{array}{l}124 \\
\text { од. }\end{array}$ & $\begin{array}{l}125 \\
\text { од. }\end{array}$ & $\begin{array}{l}126 \\
\text { од. }\end{array}$ & $\begin{array}{l}126 \\
\text { од. }\end{array}$ & $\begin{array}{l}124 \\
\text { од. }\end{array}$ & $\begin{array}{l}125 \\
\text { од. }\end{array}$ & $\begin{array}{l}126 \\
\text { од. }\end{array}$ & $\begin{array}{l}126 \\
\text { од. }\end{array}$ \\
\hline $\begin{array}{l}\text { Гранична штатна чисельність } \\
\text { працівників ЗДУ }\end{array}$ & $\begin{array}{l}1399 \\
\text { чол. }\end{array}$ & $\begin{array}{l}1394 \\
\text { чол. }\end{array}$ & $\begin{array}{l}1394 \\
\text { чол. }\end{array}$ & $\begin{array}{l}1394 \\
\text { чол. }\end{array}$ & $\begin{array}{l}1399 \\
\text { чол. }\end{array}$ & $\begin{array}{l}1394 \\
\text { чол. }\end{array}$ & $\begin{array}{l}1394 \\
\text { чол. }\end{array}$ & $\begin{array}{l}1394 \\
\text { чол. }\end{array}$ \\
\hline $\begin{array}{l}\text { Середньорічна } \\
\text { працівників ЗДУ (на штатних } \\
\text { посадах) }\end{array}$ & $\begin{array}{l}1270 \\
\text { чол. }\end{array}$ & $\begin{array}{l}1315 \\
\text { чол. }\end{array}$ & $\begin{array}{l}1273 \\
\text { чол. }\end{array}$ & $\begin{array}{l}1273 \\
\text { чол. }\end{array}$ & $\begin{array}{l}1117 \\
\text { чол. }\end{array}$ & $\begin{array}{l}1142 \\
\text { чол. }\end{array}$ & $\begin{array}{l}1247 \\
\text { чол. }\end{array}$ & $\begin{array}{l}1261 \\
\text { чол. }\end{array}$ \\
\hline $\begin{array}{l}\text { у тому числі дипломатичні } \\
\text { прачівники }\end{array}$ & - & $\begin{array}{l}894 \\
\text { чол. }\end{array}$ & $\begin{array}{l}856 \\
\text { чол. }\end{array}$ & - & - & $\begin{array}{l}776 \\
\text { чол. }\end{array}$ & $\begin{array}{l}839 \\
\text { чол. }\end{array}$ & - \\
\hline $\begin{array}{r}\text { адміністративно-технічні } \\
\text { працівники }\end{array}$ & - & $\begin{array}{l}298 \\
\text { чол. }\end{array}$ & $\begin{array}{l}392 \\
\text { чол. }\end{array}$ & - & - & $\begin{array}{l}259 \\
\text { чол. }\end{array}$ & $\begin{array}{l}384 \\
\text { чол. }\end{array}$ & - \\
\hline обслуговуючий персонал & - & $\begin{array}{l}123 \\
\text { чол. }\end{array}$ & $\begin{array}{l}25 \\
\text { чол. }\end{array}$ & - & - & $\begin{array}{l}107 \\
\text { чол. }\end{array}$ & $\begin{array}{l}24 \\
\text { чол. }\end{array}$ & - \\
\hline $\begin{array}{l}\text { Чисельність працівників ЗДУ, } \\
\text { які виконують консульські } \\
\text { функції }\end{array}$ & $\begin{array}{l}275 \\
\text { чол. }\end{array}$ & $\begin{array}{l}288 \\
\text { чол. }\end{array}$ & $\begin{array}{l}307 \\
\text { чол. }\end{array}$ & $\begin{array}{l}297 \\
\text { чол. }\end{array}$ & $\begin{array}{l}288 \\
\text { чол. }\end{array}$ & $\begin{array}{l}263 \\
\text { чол. }\end{array}$ & $\begin{array}{l}295 \\
\text { чол. }\end{array}$ & $\begin{array}{l}299 \\
\text { чол. }\end{array}$ \\
\hline
\end{tabular}

Примітка: сформовано на основі джерела: [12].

Розбіжності між фактичними показниками чисельності та затвердженими результативними показниками обумовлені, зокрема часовими факторами проведення конкурсів на заміщення вакантних посад та оформлення переможців конкурсів для направлення у закордонне відрядження [12].

Середньорічна чисельність працівників закордонних дипломатичних установ (на штатних посадах) згідно із фактичними результативними показниками за період 2017-2020 рр. має тенденцію до збільшення кількості штатних працівників (див. мал. 1). 


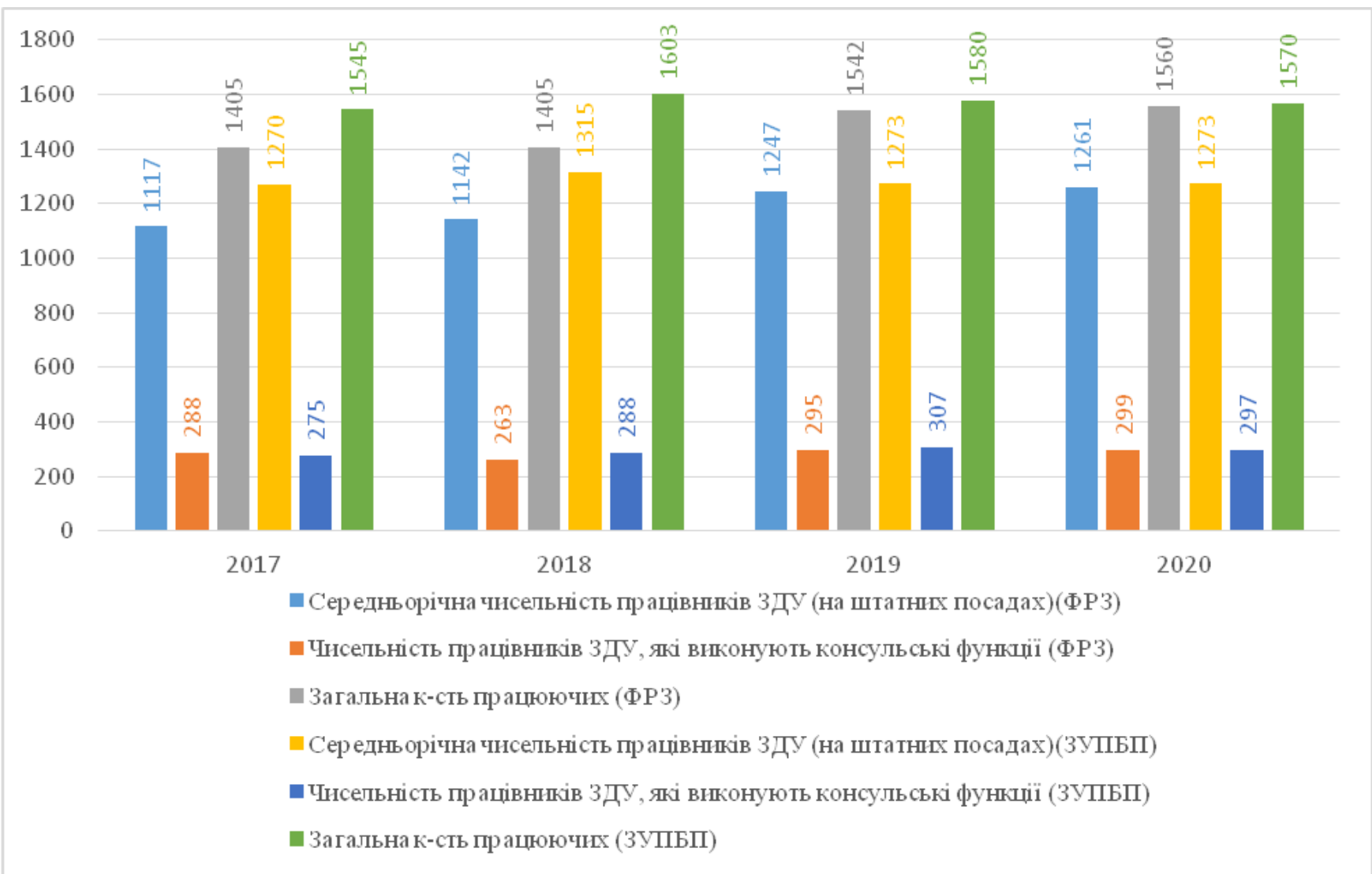

Мал. 1. Аналітична схема аналізу кадрового складу закордонних дипломатичних установ за 2017-2020 рр.

Примітка: побудовано на основі джерела: [12].

Як видно $з$ табл. 1 та рис. 1, як загальна кількість працівників дипломатичних установ, які здійснюють консульські функції, так i працівників даних дипломатичних установ (на штатних посадах) динамічно і практично рівномірно зростає 32017 по 2020 pp. Зокрема, загальна кількість працівників згідно 3 фактичними результативними показниками у 2017 році становила 1545 осіб, а в 2020 році - 1570 осіб, відповідно працівників закордонних дипломатичних установ, які виконують консульські функції у 2017 році становила 288 осіб, а в 2020 році - 299 осіб та працівників закордонних дипломатичних установ (на штатних посадах) у 2017 році становила 1117 осіб, а в 2020 році - 1261 осіб.

Впродовж періоду 2017-2020 рр. в Державному навчально-науковому закладі післядипломної освіти "Дипломатична академія України імені Геннадія Удовенка при Міністерстві закордонних справ", а також в Українській школі урядування Національного агентства України з питань державної служби та в Інституті підвищення кваліфікації керівних кадрів Національної академії державного управління при Президентові України здійснюється підготовка, для роботи у сфері міжнародних відносин, забезпечується ефективне навчання та професійно оріснтовне удосконалення знань іноземних мов на основі сучасної педагогічної науки 3 активним застосуванням технічних засобів навчання, забезпечується професійним навчанням працівників дипломатичної служби. За період 2017-2020 pp. згідно із фактичними результативними показниками та за затвердженою у паспорті бюджетною програмою 400 працівників дипломатичної служби 
підвищили кваліфікацію 3 іноземних мов та 600 працівників дипломатичної служби отримали професійне навчання (див. табл. 2).

Таблиця 2

Показники підвищення кваліфікації кадрів дипломатичної служби за 20172020 рp.

\section{Фактичні результативні показники, досягнуті за рахунок касових видатків}

Кількість працівників дипслужби, які здобули професійне навчання та $\quad 600$ чол. $(93,8 \%)$ відсоткове значення від загальної кількості працівників МЗС України

Кількість працівників дипслужби, які здобули мовну підготовку та відсоткове значення від загальної кількості працівників МЗС України

400 чол. $(62,5 \%)$

\section{Затверджено у паспорті бюджетної програми}

Кількість працівників дипслужби, які здобули професійне навчання та відсоткове значення від загальної кількості працівників МЗС України Кількість працівників дипслужби, які здобули мовну підготовку та відсоткове значення від загальної кількості працівників МЗС України

Примітка: сформовано на основі джерела: [12].

Згідно з наданими статистичними даними на початок 2020 року здійснено заходи щодо мовної підготовки та професійного навчання штатних працівників дипломатичної служби, на базі Дипломатичної академії України, та крім того у прикладних навчальних закладах в Україні та за кордоном, а саме: 551 - в Дипломатичній академії України; 58 - в Українській школі урядування Національного агентства України 3 питань державної служби; 20 - в Інституті підвищення кваліфікації керівних кадрів Національної академії державного управління при Президентові України; 56 - за кордоном.

Оцінюючи результативні показники діяльності працівників 3ДУ за 2017-2018 pp. рівень вчасно виконаних доручень у їх загальної кількості за аналізований період становить 100\%, що вказує на позитивну тенденцію діяльності працівників закордонних дипломатичних установ, а частка прийнятих нормативно-правових актів у загальній кількості розроблених у 2017 році за фактичними показниками була у 2 рази нижчою порівняно до затвердженої у паспорті бюджетної програми, у 2018 році фактичні показники були вищими на 10\%, порівняно до затвердженої у паспорті бюджетної програми, а у період 2019-2020 рр. фактичні показники були нижчими порівняно до затвердженої у паспорті бюджетної програми (див. табл. 3 ).

Таблиия 3

Результативні показники ефективної діяльності працівників ЗДУ за 2017-2020

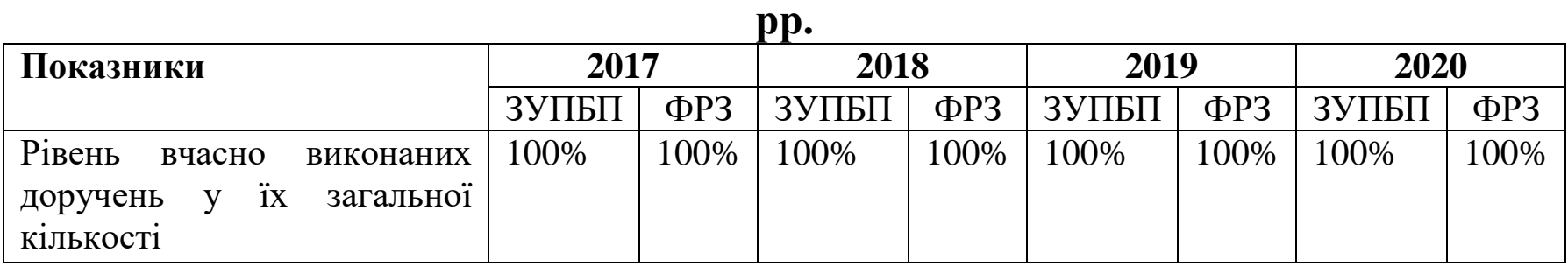




\begin{tabular}{|l|l|l|l|l|l|l|l|l|}
\hline Частка прийнятих & $100 \%$ & $50 \%$ & $50 \%$ & $60 \%$ & $60 \%$ & $51 \%$ & $65 \%$ & $61 \%$ \\
нормативно-правових актів \\
у загальній кількості \\
розроблених
\end{tabular}

Примітка: сформовано на основі джерела: [12].

Відхилення результативного показника у 2018 році пояснюється оперативним погодженням розроблених нормативно-правових актів в інших органах державної влади. Відхилення результативного показника в інших досліджуваних роках пояснюється тим, що певна частка розроблених нормативно-правових актів проходить процедуру погодження в інших органах державної влади.

В межах реформування дипломатичної служби було здійснено грунтовну та кропітку роботу з модернізації нормативно-правової бази, в результаті було розроблено 16 нормативно-правових актів, які регулюють питання проходження дипломатичної служби. Уперше на практиці відбулося втілення соціальних гарантій іншому з подружжя працівників закордонних дипломатичних установ, закріплені Законом України "Про дипломатичну службу". Практичне застосування оновлених та видозмінених нормативно-правових актів, а саме, Порядку ротації посадових осіб дипломатичної служби санкціонувало відповідним чином систематизувати проходження дипломатичної служби працівниками МЗС, забезпечити плановість службової кар'єри та наявність конкуренції на кожному етапі експансії по службі, збільшити ефективність користування людських ресурсів, забезпечити здійснення управлінської політики персоналу системною та прозорою. Законодавчо-правовим підгрунтям для приєднання місцевого персоналу для роботи в закордонних дипломатичних установах України стало затвердження Положення про працівників, які здійснюють сервісну місію в органах дипломатичної служби. Було вдосконалено конкурсну процедуру та додано зміни до Порядку проведення конкурсу на зайняття посад державної служби в частині врахування спеціальних вимог щодо осіб, які претендують на здобуття посад категорій "Б" i "В" в органах дипломатичної служби, з ціллю покращення поточної ефективності стосовно добору персоналу, суміжно затверджено Порядок визначення рівня володіння іноземною мовою кандидатами. У контексті реалізації комплексної реформи державного управління затверджено нову структуру апарату Міністерства відповідно до вимог Концепції оптимізації системи центральних органів виконавчої влади та Концепції запровадження посад фахівців з питань реформ. Враховуючи наведене, у 2019 році МЗС забезпечено реалізацію державної політики у сфері зовнішніх відносин з урахуванням цілей державної політики, мети та завдань, на досягнення котрих спрямовано реалізацію бюджетної програми [12].

Отже, державне управління в системі дипломатичної служби продемонстрував високі результативні показники, котрі спрямовані на забезпечення ефективного функціонування закордонних дипломатичних установ.

Висновки. Проаналізувавши вищевикладене, можна узагальнити, що дипломатична служба відіграє важливу роль у формуванні зовнішньополітичного вектору країни та $є$ одним із ключових елементів у сфері державного управління. 
Аналіз сучасного складу працівників дипломатичної служби за кількісними та якісними показниками, свідчить про незбалансованість кадрового складу Міністерства закордонних справ за фаховою та мовною підготовкою, рівнями посад та необхідними напрямами діяльності. Дана ситуація формує труднощі в якісній розстановці та ефективному використанні кадрів, задля здійснення ротації, що в результаті негативно позначається на поточному функціонуванні дипломатичної служби.

Удосконалення кадрової політики є важливою складовою частиною процесу розвитку державного управління в системі дипломатичної служби України, які повинні забезпечувати об'єктивне з'ясування як професійних, так і особистих якостей кандидатів на заміщення вакантних посад, а також необхідно формувати якісний кадровий резерв, враховуючи при цьому можливі довготривалі закордонні відрядження та працевлаштування після повернення 3-за кордону. Важливим моментом кадрового забезпечення $€$ мотивація кадрів задля ефективної професійної діяльності, котра включає матеріальні та нематеріальні чинники, проте дана мотивація є неналежною та потребує удосконалення, тому необхідно розробити та прийняти відповідні правки до чинного законодавства.

\section{Jimepamypa:}

1. Карпа М. I. Методи управління кадровими процесами у контексті становлення публічної служби в Україні. Ефективність державного управління. 2013. Вип. 37. С. 354-362. URL: http://nbuv.gov.ua/UJRN/efdu_2013_37_49 (дата звернення 05.09.2020).

2. Енциклопедія державного управління : у 8 т. / наук.-ред. кол. : Ю. В. Ковбасюк (голова) [та ін.] ; Національна академія державного управління при Президентові України. Київ : НАДУ, 2011. Т. 8 : Публічне врядування / наук.-ред. кол. : В. С. Загорський (голова), C. О. Телешун (співголова) [та ін.] ; Львівський регіональний інститут державного управління Національна академія державного управління при Президентові України. Львів : ЛРІДУ НАДУ, 2011. 630 с.

3. Про затвердження Порядку ротації посадових осіб дипломатичної служби в органах дипломатичної служби : Наказ МЗС України від 18.10.2018 № 427 // Відомості Верховної Ради України. URL: https://zakon.rada.gov.ua/laws/show/z1274-18\#Text (дата звернення 05.09.2020).

4. Пахомова Н. I. Удосконалення механізмів підбору кадрів дипломатичної служби України. Економіка та держава. 2011. № 10. C. 66-67. URL: http://www.economy.in.ua/pdf/10_2011/20.pdf (дата звернення 05.09.2020).

5. Гончарова А. О. Дипломатична служба як складова частина державної служби України. Актуальні проблеми державного управління. 2011. № 1. C. 420-424. URL: http://nbuv.gov.ua/UJRN/apdy_2011_1_51 (дата звернення 05.09.2020).

6. Про дипломатичну службу України : Закон України від 20.09.2001 № 2728-III // Відомості Верховної Ради України. URL: http://zakon4.rada.gov.ua/laws/show/2728-14 (дата звернення 05.09.2020).

7. Про затвердження Положення про Міністерство закордонних справ України: Указ Президента України від 06.04.2011 № 381/2011 // Відомості Верховної Ради України. URL: http:// zakon4.rada.gov.ua/laws/show/381/2011 (дата звернення 05.09.2020).

8. Про державну службу : Закон України від 16.12.1993 № 3723- XII : із зм. і доп. станом на 16.07.2020 // Відомості Верховної Ради України. URL: https://zakon.rada.gov.ua/laws/show/88919\#Техt (дата звернення 05.09.2020).

9. Про затвердження Порядку проведення конкурсу для прийняття на дипломатичну службу : Постанова КМУ від 16.11.2002 № 1754 // Відомості Верховної Ради України. URL: http:// https://ips.ligazakon.net/document/view/kp021754?an=684 (дата звернення 05.09.2020). 
10. Гуменюк Б. І., Щерба О. В. Сучасна дипломатична служба : [навч. посіб.]. Київ : Либідь, 2001. 255 с.

11. Чмельова О. С., Чуйко Ю. В. Сучасна дипломатична служба України як гарант ефективних міжнародних відносин. Стратегії інноваційного розвитку економіки України: проблеми, перспективи, ефективність "Форвард-2016" : тр. 7-ї Міжнар. наук.-практ. Internetконф. студ. та молодих вчених, 27 грудня 2016 р. / ред. П. Г. Перерва, Є. М. Строков, О. М. Гуцан. Харків : НТУ "ХПІ", 2016. С. 269-270.

12. Офіційний сайт Міністерства закордонних справ України. URL: https://mfa.gov.ua/ (дата звернення 05.09.2020).

\section{References:}

1. Karpa, M.I. (2013), "Methods of personnel process management in the context of public service in Ukraine", Efektyvnist' derzhavnoho upravlinnia, [Online], vol. 37. pp. 354-362. available at: http://nbuv.gov.ua/UJRN/efdu_2013_37_49 (Accessed 5 September 2020).

2. Kovbasiuk, Yu.V., Zagorsky, V.S. \&, Teleshun, S.O. (Eds.). (2011). Entsyklopediia derzhavnoho upravlinnia [Encyclopedia of public administration]. Vol. 8. Kyiv: NADU. Publichne vriaduvannia [Public governance]. Lviv: LRIDU NADU, $630 \mathrm{p}$.

3. The Ministry of Justice of Ukraine (2018), The Order of the Ministry of Foreign Affairs of Ukraine "On approval of the Procedure for rotation of officials of the diplomatic service in the bodies of the diplomatic service", available at: https://zakon.rada.gov.ua/laws/show/z1274-18\#Text (Accessed 5 September 2020).

4. Pakhomova, N.I. (2011), "Improving the mechanisms of recruitment of the diplomatic service of Ukraine", Ekonomika ta derzhava, [Online], vol. 10. pp. 66-67, available at: http://www.economy.in.ua/pdf/10_2011/20.pdf (Accessed 5 September 2020).

5. Honcharova, A.O. (2011), "Diplomatic service as an integral part of the civil service of Ukraine", Aktual'ni problemy derzhavnoho upravlinnia, [Online], vol. 1. pp. 420-424, available at: http://nbuv.gov.ua/UJRN/apdy_2011_1_51 (Accessed 5 September 2020).

6. The Verkhovna Rada of Ukraine (2001), The Law of Ukraine "On the diplomatic service of Ukraine", available at: http://zakon4.rada.gov.ua/laws/show/2728-14 (Accessed 5 September 2020).

7. The Decree of the President of Ukraine (2011), "On approval of the Regulation on the Ministry of Foreign Affairs of Ukraine", available at: http:// zakon4.rada.gov.ua/laws/show/381/2011 (Accessed 5 September 2020).

8. The Verkhovna Rada of Ukraine (1993), The Law of Ukraine "On civil service", available at: https://zakon.rada.gov.ua/laws/show/889-19\#Text (Accessed 5 September 2020).

9. The Verkhovna Rada of Ukraine (2002), The Resolution of the Cabinet of Ministers of Ukraine "On approval of the Procedure for holding a competition for the admission of the diplomatic service", available at: http://https://ips.ligazakon.net/document/view/kp021754?an=684 (Accessed 5 September 2020).

10. Humeniuk, B.I. and Scherba, O.V. (2001), Suchasna dyplomatychna sluzhba [Modern diplomatic service], Lybid', Kyiv, Ukraine.

11. Chmelyova, O.S. and Chuyko Yu.V. (2016), "Modern diplomatic service of Ukraine as a guarantor of effective international relations", Stratehii innovatsijnoho rozvytku ekonomiky Ukrainy: problemy, perspektyvy, efektyvnist' "Forvard-2016" [Strategies of innovative development of the economy of Ukraine: problems, prospects, efficiency "Forward-2016"], International scientific-practical Internet-conference of students and young scientists [Mizhnarodna naukovo-praktychna Internetkonferentsiia studentiv ta molodykh vchenykh], National Technical University "Kharkiv Polytechnic Institute", Kharkiv, Ukraine, pp. 269-270.

12. The official site of the Ministry of Foreign Affairs of Ukraine. available at: https://mfa.gov.ua/ (Accessed 5 September 2020). 